\title{
Determinant Indicators of Turnover Intentions, Work Productivity, Work Safety, Health and Human Relations \\ by
}

\section{Ida Ayu Iswari Pidada}

Universitas Pendidikan Nasional

iaiswaripdd@gmail.com

\begin{abstract}
This research aimed to Analyze indicators (1) safety affect the work productivity of employees at Melia Bali hotel Nusa Dua?, (2) health affect employee work productivity at Melia Bali hotel Nusa Dua?, (3) human relations influence employee work productivity at Melia Bali hotel Nusa Dua?,(4) safety affect employee turnover intentions at the Melia Bali hotel Nusa Dua?, (5) health affect employee turnover intentions at Melia Bali hotel Nusa Dua?, (6) work productivity affect employee turnover intentions at Melia Bali hotel?. Which all the reasons of this research is aimed to Analyze indicators that determine turnover intentions. This research used quantitative method. The subject in this study involved 115 employees. The Collecting data method used observation and questionnaire. The sampling method in this study using a type of non-probability sampling with combination method: purposive samplingaccidental sampling-quota sampling. The collected data analyzed with SEM analysis of AMOS version 20.0.

The results showed that there is a highly significant influence of Safety, Health, Human Relation, and Employees productivity towards Turnover intentions employees. In addition, based on the simple regression analysis model that indicated a positive and significant influence of Safety, Human Relation, toward Employees productivity. Then, there is a positive and highly significant influence between Employees productivity towards Turnover intentions.
\end{abstract}

Keywords: Safety, Health, Human Relation, Productivity, Turnover Intention 


\section{INTRODUCTION}

Nowadays, the latest developments see employees not as only resources, but rather in the form of capital or assets for institutions or organizations. Therefore, a new term emerged outside HR (Human Resources), namely HC or Human Capital. Here HR is seen not only as a major asset, but assets that are valuable and can be multiplied, developed (in comparison with investment portfolios) and therefore not considered to be a liability (expense, cost). Here the perspective of $\mathrm{HR}$ as an investment for institutions or organizations is more prominent. Human resources (HR) is one of the most important factors that cannot even be separated from an organization, both institutions and companies. HR is also the key that determines the development of the company. In essence, human resources in the form of humans who are employed in an organization play as a driver to achieve the goals of the organization.

Judging from its definition, HR performance is closely related to the influence of leadership style as well as the productivity of the employer. In general, productivity is defined as the relationship between tangible and physical results with actual input (ILO, 1979). Greenberg cited by Sinungan (1985) defines productivity as a comparison between the totality of expenditure at a given time divided by the totality of inputs during that period.

In Indonesia, the number of work accidents shows a very alarming rate. Even according to research by the International Labor Organization (ILO). Indonesia ranks 52nd out of 53 countries with bad K3 management. Even though the costs that will be incurred by the company will be very large if an accident occurs at the workplace. (Hanggraeni, 2012).

According to data from the International Labor Organitation (ILO) in 2010, more than 2 million people died each year from work-related accidents and diseases. Around 160 million people suffer from work-related illnesses and there are around 270 million annual workplace accidents throughout the world (ILO 2009 in Ramli, 2010)

Not only K3, the comfort of employees in work must be taken into account as it can create effective ways of working thus increasing the productivity of their performance. By using a simple way of working, the use of tools that can help speed up the completion of tasks and save motion and energy, someone can be said to work efficiently and obtain satisfactory results, it is expected to reduce the level of turnover intention in a company.

The occurrence of work accidents certainly makes a big problem for the survival of a business. The losses suffered are not only in the form of material losses which are quite large but more than that are the emergence of a number of casualties. This loss of human resources is a huge loss because humans are the only resource that cannot be replaced by any technology. (Gravel, Rheaume \& Legendre, 2011) 
Turnover intention is also defined as a person's behavioral attitude to withdraw from the organization (Aydogdu \& Baris, 2011). This opinion shows that turnover intention is the desire to move, something that has not arrived at the realization stage yet, namely moving from one workplace to another. Turnover intention is considered as the perception of employees to leave the organization caused by various factors such as job dissatisfaction, salary dissatisfaction, etc. (Mlambo, 2013) The following is a table of turnover percentage in each division between 2012-2016 at Melia Bali Hotels:

Table 1.1

Percentage of Turnover Rates in each division in 2013 - 2017 Melia Bali Hotels.

\begin{tabular}{|c|l|c|c|c|c|c|}
\hline No. & \multicolumn{1}{|c|}{ Division } & 2013 & 2014 & 2015 & 2016 & 2017 \\
\hline 1 & Sales and Marketing & $2 \%$ & $4,5 \%$ & $6 \%$ & $9 \%$ & $13 \%$ \\
\hline 2 & Housekeeping & $1 \%$ & $3 \%$ & $7 \%$ & $10 \%$ & $10 \%$ \\
\hline 3 & Front Office & $5 \%$ & $9 \%$ & $4 \%$ & $13 \%$ & $15 \%$ \\
\hline 4 & F\&B Service & $6 \%$ & $4 \%$ & $8 \%$ & $12 \%$ & $14 \%$ \\
\hline 5 & Entertainment & $3 \%$ & $2 \%$ & $6 \%$ & $8 \%$ & $10 \%$ \\
\hline 6 & F\&B Kitchen & $4 \%$ & $8 \%$ & $5 \%$ & $7 \%$ & $8 \%$ \\
\hline 7 & Accounting & $5 \%$ & $3 \%$ & $2 \%$ & $4 \%$ & $6 \%$ \\
\hline
\end{tabular}

(Source: HDR Melia Bali Hotel, 2018.)

Based on the above background, the problems that can be formulated in this study are: (1) Does safety affect the work productivity of employees at Melia Bali hotel Nusa Dua?; (2) Does health affect employee work productivity at Melia Bali hotel Nusa Dua?; (3) Does human relations influence employee work productivity at Melia Bali hotel Nusa Dua?; (3) Does safety affect employee turnover intentions at the Melia Bali hotel Nusa Dua?; (4) Does health affect employee turnover intentions at Melia Bali hotel Nusa Dua? ; (5) Does work productivity affect employee turnover intentions at Melia Bali hotel?

\section{LITERATURE REVIEW}

\section{Safety}

According to Swasto (2011), work safety involves all processes of labor protection against the possibility of hazards arising in the work environment. 
Work safety according to Sugeng in Lambrie (2010) is defined as activities aimed at preventing all types of accidents that have to do with the environment and work situations. Meanwhile, Swasto, (2011) suggested that work safety involves all processes of labor protection against the possibility of hazards arising in the work environment.

According to Moenir in Rahman (2009), indicators of safety are as follows:

$\mathrm{X}_{1}$ : Placement of objects or goods.

$\mathrm{X}_{2}$ : Protection of employees or workers.

$\mathrm{X}_{3}$ : Provision of equipment as prevention, aid and protection.

$\mathrm{X}_{4}$ : Provision of accident prevention socialization programs.

\section{Health}

Swasto (2011) suggested that occupational health concerns physical and mental health. Health covers all aspects of human life including the work environment. According to Rijuna Dewi (2006) indicators of health variables are:

$\mathrm{X}_{5}$ : Company attention to the health aspects of employees

$\mathrm{X}_{6}$ : Completeness of health facilities.

$\mathrm{X}_{7}$ : Health service procedures.

$\mathrm{X}_{8}$ : Working hours.

$\mathrm{X}_{9}$ : Workload.

$\mathrm{X}_{10}$ : Health Insurance

\section{Human Relations}

According to Handayani, Kusmiyati \& Tyastuti, (2010) Human Relations in the Broad Definition is the interaction between someone and others in all situations and in all areas of life. Human nature as a thinking creature (Homo sapiens) and thus distinguishes it from animals, also play roles as social beings (Homo sosius) so that in their lives they are always associated with society and the environment. According to Istijanto (2010) the indicators of human relations are as follows:

$\mathrm{X}_{11}$ : Relationships with coworkers

$\mathrm{X}_{12}$ : Relationships with superiors

$\mathrm{X}_{13}$ : Client relations

$\mathrm{X}_{14}$ : Relationships with the community 


\section{Work Productivity.}

Work productivity is the ability to produce a work that is more than the usual size of what has been commonly accepted, The Liang Gie (2010). The productivity of human resources is closely related to the management of human resources, where human resource management does not always take into account the achievement of productivity in each policy, procedures or systems that cover it. According to Simamora (2004) labor productivity indicators are as follows:

$$
\begin{aligned}
& \mathrm{X}_{15} \text { : Work Quantity. } \\
& \mathrm{X}_{16} \text { : Quality of Work } \\
& \mathrm{X}_{17} \text { : Use of Time. }
\end{aligned}
$$

\section{Turnover Intention}

According to Waspodo, et al (2013) turnover intention is the desire of someone to leave the company and try to find another job that is better than before. According to Raabe and Beehr in Putra (2012), Turnover Intention is defined as someone's desire to leave the company. An employee who feels satisfied in his job will show, in general, a good attitude in the workplace and would cause increased commitment to the organization which will result in low intention to leave the company. According to Lum et al (1998) in Kucoro (2012) indicator of turnover intentions are as follows:

$$
\begin{aligned}
& \mathrm{X}_{18}: \text { Intention to quit } \\
& \mathrm{X}_{19}: \text { Job search } \\
& \mathrm{X}_{20} \text { : Thinking of quit }
\end{aligned}
$$

\section{Previous research :}

\section{Effect of safety against employee work productivity.}

As mentioned by Andriana Pusparini, Jusuf, and Sugeng Budiono (2008), one of the goals of work safety programs is to protect workers of their right to safety in carrying out work for their welfare and to increase production and productivity. Then, Anwar Prabu Mangkunegara (2007), stated that with the existence of work safety programs, it will increase the enthusiasm, productivity, and work participation of workers. In line with what was conveyed by Andriana Pusparini, Jusuf, Sugeng Budiono, and Anwar Prabu Mangkunegara, it was also emphasized by Sedarmayanti (2009) that work safety programs would increase the work productivity of workers. 


\section{The influence of health on employee productivity.}

Suma'mur (1996), argues that health in work environment is a specialization of health or medical sciences along with its practice that aims for workers or the community to obtain the highest degree of health physically, mentally and socially, with preventive and curative efforts on the work itself, work environment and general illness factors.

\section{Effect of human relations on employee work productivity.}

The ability to create a conducive atmosphere, implicitly has two meanings. On the one hand it requires the maturity of the leadership in understanding the complexity of the organization and the process of interaction between units within the overall organizational framework as well as the ability to use the knowledge of engineering methods and equipment needed in the implementation of each of its activities. On the other hand, it requires the leadership to seriously apply the principle of Human Relations or humanitarian work relations within the framework of formal and informal relationships between superiors and subordinates, among fellow bosses and among subordinates so as to create harmonious and intimate working relationships yet still dynamic and acceptable.

\section{Effect of safety on employee turnover intentions}

Work safety defined in this study covers employee expectations for the continuity of work, promotion opportunities, general working conditions and long-term career opportunities.

If the employee feels that the company where he/she is currently working can provide assurance regarding the factors included in work safety, employee satisfaction and performance will increase. Based on empirical evidence, work safety is an important determinant of labor health, the physical and psychological life of employees (Jacobson, 1991), employee resignation (Arnold and Feldman, 1982); employee retention (Ashford et al, 1989; Davy et al, 1997; Vinokur-Kaplan et al, 1994), and organizational commitment (Ashford et al, 1989; Bhuian and Islam, 1996; Iverson, 1996).

\section{Effect of Health on employee turnover intentions.}

Health in the scope of work safety is not only interpreted as a condition free from disease and its application that aims to create a healthy workforce, productive in work, is in a steady in terms of work capacity, workload and working environment conditions, as well as protected from diseases caused by work and work environment (Suma'mur, 2009). 


\section{Effect of work productivity on employee turnover intentions.}

Employees who actively participate in their work demonstrate the willingness and desire of employees to be directly involved in work. Woodward and Buchholz (1987, in Akinbobola, 2011) explain that when an employee has a low job involvement, he/she will become someone who is physically present but mentally absent. When an employee is fully involved in his/her work, energy and focus are aimed directly at the involvement. Employees become organizational assets and will not be able to think of leaving the organization when they have high work involvement while low work involvement adds to the feeling of employees of alienation in the organization or a feeling of separation between what employees see as life and the work they do (Hafer and Martin, 2006, in Akinbobola).

Based on the problem formulation, literature, and theoretical frameworks raised in this study, the hypothesis that can be formulated in the study are as follows:

H1 : The better the safety of the company is, the higher the level of work productivity of employees.

$\mathrm{H} 2$ : The better the health that employees have, the higher the level of work productivity of employees.

H3: The better the human relations are, the more the level of work productivity of employees.

H4: The better the work safety is, the lower the rate of employee turnover intentions would be.

H5: The better the work health is, the lower the rate of employee turnover intentions would be.

H6: The better the work productivity that employees have, the lower the rate of employee turnover intentions would be.

\section{RESEARCH METHODS}

This research is quantitative research conducted by using a survey method through the filling of sematic differential scale questionnaires and the object of the research is employees at the Melia Bali Hotel Nusa Dua. The types and sources of data used in this study consist of primary data and secondary data. Data collection techniques were questionnaires, interviews, and observations. Data is processed through the stages of editing, scoring, and tabulating. This research uses quantitative methods. The subjects in this study involved 115 employees. Methods of collecting data were observation and questionnaires. Data collected was analyzed by AMOS path analysis version 20.0 
Figure 1.1

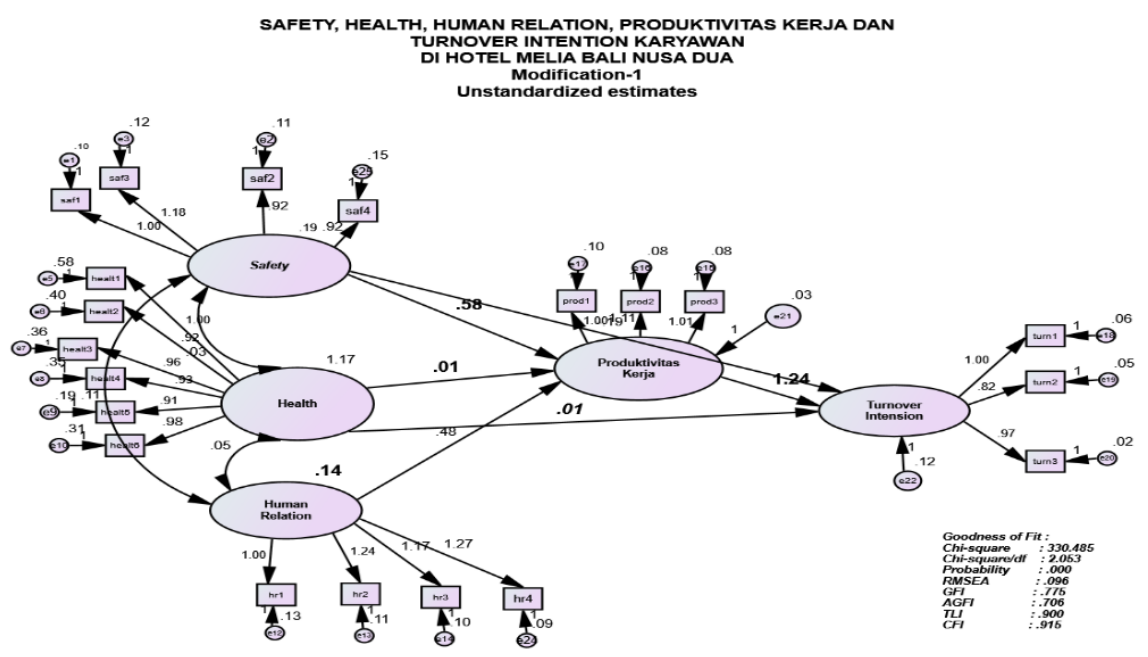

Source: Processed Data.

\section{RESULTS AND DISCUSSION}

In this study the authors will use a descriptive quantitative approach. Where the researcher made direct observations at the Melia Bali Indonesia Hotel in order to get a precise and clear picture of the problems found during conducting research. Viewed from the characteristics based on sex, the respondents who were male were 67 (58\%) and the correspondents who were female were 48 people (42\%). So it can be concluded that the employees of Melia Bali Indonesia Hotel are more male than female. Judging from the characteristics of respondents based on age, it looks balanced between respondents aged 20-30 years which amounted to 58 people, and 31-50 years which amounted to 57 people. There are no respondents over 50 years old at the Melia Bali Indonesia Hotel. Seen from the characteristics of respondents based on marital status, employees with marital status were amounting to 73 people (63.48\%) and unmarried employees were only 42 people or $36.52 \%$.

Referring to the picture above and the data collected, data processing is performed using SEM analysis by using AMOS version 20.0 software to obtain a graphical display and the results of Regression weight, which can be tested by conducting the Goodness of fit analysis, analysis of structural models, analysis of determination, analysis of measurement models with lamda parameters for safety, health, human relations, work productivity, and turnover intentions which shall produce the following: 
Table 1.2

Evaluation of Goodness of fit

Full Model

\begin{tabular}{|c|c|c|c|}
\hline $\begin{array}{c}\text { Goodness of fit } \\
\text { index }\end{array}$ & Cut-of value & Results Model & Description \\
\hline Chi-square $\left(\chi^{2}\right)$ & Expected Small & $\mathbf{3 3 0 , 4 8 5}$ & Less Good \\
\hline Chi-square $\left(\chi^{2} /\right.$ df $)$ & $\leq 3,00$ & 2,053 & Good \\
\hline Probability & $\geq 0.05$ & 0,000 & Moderate \\
\hline RMSEA & $\leq 0.08$ & 0.096 & Less Good \\
\hline GFI & $\geq 0.90$ & 0.775 & Less Good \\
\hline AGFI & $\geq 0,90$ & 0.706 & Less Good \\
\hline TLI & $\geq 0.95$ & 0.900 & Less Good \\
\hline CFI & $\geq 0.95$ & 0.915 & Less Good \\
\hline
\end{tabular}

Source: Processed Data.

Noting the value of the cut-of-value and the goodness of fit of the model results in Table 1.2 above, it appears that one criterion is well fulfilled from the eight criteria used. The criteria fulfilled are Relative Chi-square ( $\left.\chi^{2} / \mathrm{df}\right)$ and 1 medium criterion, namely Probability and the other six criteria stated to be less good, consisting of RMSEA, GFI, AGFI, TLI and CFI. Because one criterion is fulfilled from the eight criteria that are required, then the above model can be stated as a model that is not good so that it is deemed necessary to modify the model, (Solimun, 2006).

The following is a modification of the first model: 
Figure 1.2

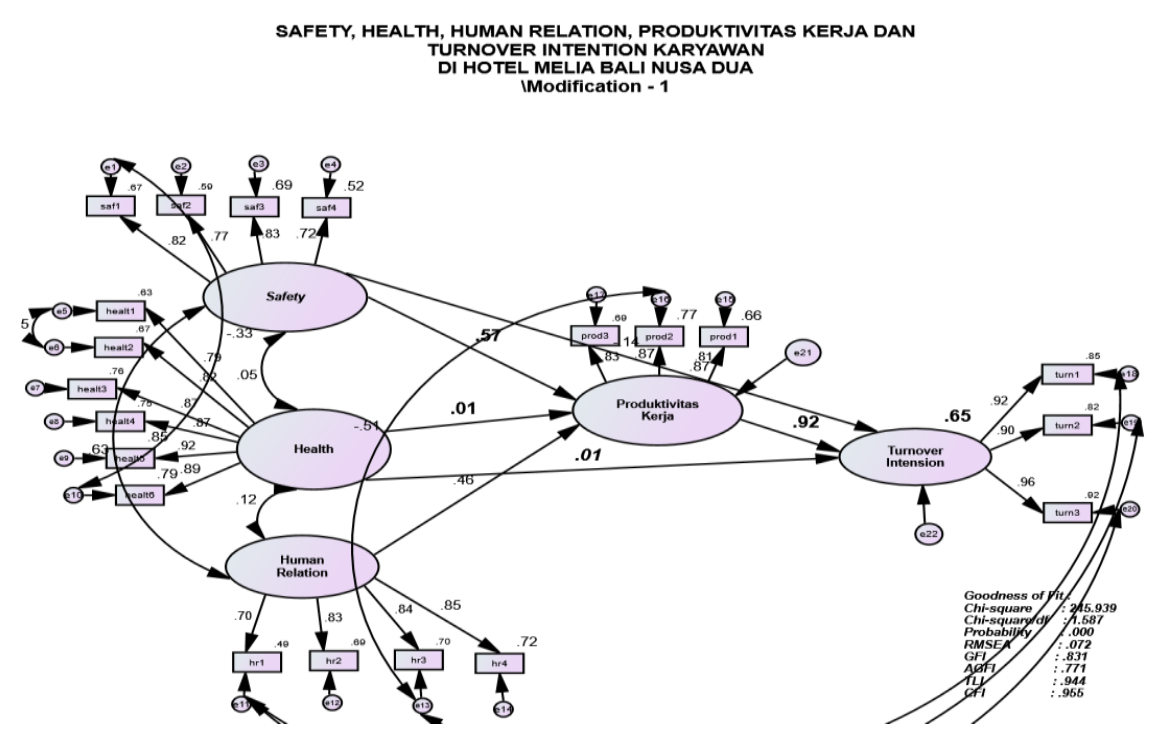

Source: Processed Data.

Table 1.3

Comparison of Main Model Results with Modified Model Results.

\begin{tabular}{|c|c|c|c|c|}
\hline $\begin{array}{l}\text { Goodness of fit } \\
\text { Index }\end{array}$ & Cut-of value & Main Model & Modification Model & Information \\
\hline Chi-square $\left(\chi^{2}\right)$ & Expected small & 330,485 & 245,939 & Better \\
\hline Chi-square $\left(\chi^{2} / \mathrm{df}\right)$ & $\leq 3,00$ & 2,053 & 1,587 & Better \\
\hline Probability & $\geq 0,05$ & 0,000 & 0,000 & Average \\
\hline RMSEA & $\leq 0.08$ & 0.096 & 0.072 & Less Good \\
\hline GFI & $\geq 0.90$ & 0.775 & 0.831 & Better \\
\hline AGFI & $\geq 0.90$ & 0.706 & 0.771 & Better \\
\hline TLI & $\geq 0.95$ & 0.900 & 0.944 & Better \\
\hline CFI & $\geq 0.95$ & 0.915 & 0.955 & Better \\
\hline
\end{tabular}

Source: Processed Data., 2018 
If seen from the Goodness of Fit, it can be seen that the modified model shows an increase to a better direction, so it can be stated that it has had a change in the first modification. When viewed from regression weight exogenous variables with endogenous variables, it turns out that in this modification there is a regression coefficient (Standardized regression weight) which is getting better.

\section{Effect of safety on employee productivity.}

Based on the results of the analysis, hypothesis stating that the better the safety of the company is, the higher the level of work productivity of employees has standardized estimated (regression weight) of 0.105 with CR (Critical Ratio = identical to the t-count value) of 5.876 and on probability $* * *$ (smaller 0.001$). \mathrm{CR}$ value $=5.876>2,000$ and probability $(* * *)<0.001$ which shows that the effect of the Safety variable on Work Productivity has a significant positive effect.

Companies must understand that good work safety is to provide employees with personal protective equipment, pay attention to the conditions of work equipment, carry out tools maintenance, provide good raw materials, provide good lighting at work sites, and maintain cleanliness and order. If the company can fulfill these things, the employee will work more comfortably without worrying about a work accident, so that employees are more productive in their work. (Muhammad Busyairi, La Ode Ahmad Safar Tosungku and Ayu Oktaviani, 2004)

Work safety is closely related to increasing productivity. Work safety can help increase productivity as by having a high level of work safety, work accidents that occur due to illness as well as disability that could lead to death can be minimized.

\section{The influence of health on employee work productivity.}

Based on the results of the analysis, hypothesis stating that the better the health of employees is, the higher the level of work productivity of employees has standardized estimated (regression weight) of 0.024 with $\mathrm{CR}$ (Critical Ratio = identical to the t-count) of 0.201 and on probability 0.841 . The value of $\mathrm{CR}=0.201<2,000$ and probability $0.841>0.001$ which shows that the influence of the Health variable on Work Productivity has a positive and insignificant effect.

The work health program is also closely related to employee work productivity even though it does not have a very significant effect. Because the work health program shows a condition that is free of physical disturbances and leads to an increase in employee productivity. 


\section{Effect of Human Relation on employee work productivity.}

Based on the results of the analysis, hypothesis stating that the better human relations are, the higher the level of work productivity of employees has standardized estimated (regression weight) of 0.111 with CR (Critical Ratio = identical to the t-count value) of 4.819 and on probability $* * *$ (more small 0.001 ). $\mathrm{CR}=4.819>2,000$ and probability $(* * *)<0.001$ which shows that the effect of the Human Relation (HR) variable on Work Productivity has a significant positive effect.

In the theoretical study, Human Relations is a process of efforts to provide motivation and to create a harmonious work atmosphere for humans in the organization to build effective and productive cooperation by meeting their needs and accepting organizational goals. Afterwards, there is another definition which states that human relations is integrating people into a work situation that encourages them to work together productively and in a spirit of cooperation with satisfaction in terms of economic, psychological and social satisfaction.

Based on this concept, it is clear that the application of Human Relations concept has a very important and significant influence in improving Employee Performance in the office through an increase in work relations between leaders and subordinates as well as among other subordinates in a work environment, applying work discipline, in accordance with the determined procedures and rules, giving incentives that satisfy employees which thus expected to improve work competencies and better Employee Performance.

\section{The effect of Safety on employee turnover intentions.}

Based on the results of the analysis, hypothesis stating that the better the work safety is, the lower the turnover intentions the employee has a standardized estimate (regression weight) of 0.265 with CR (Critical Ratio = identical to the t-count value) of -0.791 and on the probability of 0.429 . The value of $\mathrm{CR}=-0.791<2,000$ and probability $0.429>0.001$ which shows that the effect of the Safety (SAF) variable on Turnover intentions (TI) has a positive and insignificant effect.

Work safety cannot only increase employee work productivity but can also reduce turnover intentions of company. Many reasons relating to safety are also one of the issues of employee discomfort which could lead to the desire to leave the organization or company. Thus it can be concluded that there is an influence of work safety on turnover intensions, although not significant. 


\section{Effect of Health on employee turnover intentions.}

Based on the results of the analysis, hyothesis stating that the better the work health is, the lower the level of turnover intentions employees has standardized estimated (regression weight) of 0.038 with CR (Critical Ratio = identical to the t-count value) of 0.213 and on the probability of 0.832 . $\mathrm{CR}$ value $=0.038<2,000$ and probability $0.832>0.001$ which shows that the Health (HLT) variable on Turnover intentions (TI) has a significant positive effect.

Similar to work safety, health is also very important to reduce employee turnover intentions. The clearer the health facilities provided, and the cleaner and safer the company is, the higher the level of health in the company which leads to the suppression of reasons for the desire to move for employees. Thus it can be concluded that there is an influence between health and turnover intention even though it does not have a significant effect.

\section{Effect of Work Productivity towards employee turnover intentions.}

Based on the results of the analysis, hypothesis stating that the better the work productivity that employees have, the lower the turnover intentions the employee has standardized estimated (regression weight) of 0.256 with CR (Critical Ratio = identical to the $\mathrm{t}$-count value) of 4.850 and on the probability $* * *$ (smaller than 0.001 ). CR value $=4.850>$ 2,000 and probability $(* * *)<0.00$ which shows that the influence of the Work Productivity $(\mathrm{PK})$ variable on Turnover intentions (TI) has a significant positive effect.

According to Cascio (in Ferry, 2007), humans are very important resources in the industrial and organizational fields, therefore management of resources includes the provision of productive and quality labor, maintenance quality and the control of labor costs.

The company's demands on employees sometimes make the company less concerned with the needs and desires of employees, while the compensation given to employees is not sufficient so employees feel uncomfortable and become disloyal. The inconvenience of this employee will cause things that have bad consequences for the company and the employees concerned. The desire to move / turnover intentions is one of the things that will emerge when the discomfort is felt by the employee. Provision of adequate work safety and health equipment with good relationships between people will create productive performance which would minimize the level of desire to move from the employee. (Norita, 2014) 


\section{CONCLUSION}

With an in-depth explanation of the results of the research done to find out the influence of safety, health, human relations, and labor productivity on turnover intentions using SEM analysis method, the following results are found:

1. The direct effect of Safety on Work Productivity has a significant positive effect.

2. The direct effect of Health on the Work Productivity has a positive effect but is not significant.

3. The direct effect of Human Relation on Work Productivity has a significant positive effect.

4. The direct effect of Safety on Turnover intentions has no significant positive effect.

5. The direct effect of Health on Turnover intentions has a positive and insignificant effect.

6. The direct effect of Work Productivity to Turnover intentions has a significant positive effect.

\section{BUSINESS IMPLICATIONS.}

Based on the results of the research obtained, the suggestions that can be put forward are as follows:

1. The existence of the willingness to move or turnover intentions due to safety, health, human relations and work productivity can be used as a reference by the management of Melia Bali Hotel to suppress the amount of turnover.

2. From this research, it is also expected that the management of Melia Bali Indonesia Hotel will also pay more attention to the health insurance provided to employees.

3. It is expected that other problems in Melia Bali Hotel should be handled by carrying out further research involving respondents who are available and assisted with the existing primary data, so that prevention and improvement measures are clear.

4. From the research that has been done at Melia Bali Indonesia Hotel, implementing a good safety system will cause or create good employee productivity.

5. From the research that has been done at the Melia Bali Hotel, the management must also improve the relations between employees to reduce the turnover rate at the company. 


\section{LIMITATIONS OF RESEARCH.}

In this research, of course there were limitations faced by the author, such as the following:

1. There were limitations to the study by using questionnaires that sometimes in the distribution of questionnaires to respondents who do not understand the intent of the questions submitted, and therefore required the author to explain first to the respondent.

2. In this analysis process the author had limitations, considering that the author examined not in the workplace the writer and the writer could only take advantage of work breaks to collect data from the questionnaire.

3. And this study should be done under a tight time constraint, and therefore it must be done quickly and with maximum results. 


\section{REFERENCES}

Arbuckle, J.L. (1997). Amos User's Guide Version 3.6. Chicago: Smallwaters Corporation.

Busyairi, M., La Ode Ahmad Safar Tosungku., dan Ayu Oktaviani. (2004). Pengaruh Keselamatan Kerja dan Kesehatan Kerja Terhadap Produktivitas Kerja Karyawan.

Christina., Sujianto., Indrawati. (2003). Komunikasi kebidanan. Jakarta: EGC. P. 34-35.

Darma, G.S. (2006). Mobile Marketing: Sebuah Strategi Keunggulan Bersaing Online. Denpasar: Undiknas Press.

Ferdinand, A. (2014). Metoda Penelitian Manajemen. Edisi 5. Semarang: Badan Penerbit Universitas Diponogoro.

Ferdinand, A. (2014). Structural Equation Modelling. Edisi 5. Semarang: Badan Penerbit Universitas Diponogoro.

Handayani., Kusmiyati., Tyastuti. (2010). Komunikasi dan konseling dalam pelayanan kebidanan. Yogyakarta: Fitramaya. P. 25-6, 28-9, 29-31, 31-2.

Mlambo, L. (2013). Impact of Psychological Factors on Employee Turnover Intention, International Journal of Research in Commerce, Economics \& Management, 3: 1041 .

Mangkunegara, A.P. (2007). Manajemen Sumber Daya Manusia. Bandung: PT. Remaja Rosdakarya.

Norita. (2014). Pengaruh Kompensasi dan Loyalitas Karyawan Terhadap Intensi Turnover di PT. Eramart Group Samarinda, E-Jurnal.

Romauli, S. (2013). Komunikasi Kebidanan. Jakarta: CV. Trans Info Media. P. 39, 40-1, 41-2, $42-3,43-4$.

Sedarmayanti. (2009). Tata Kerja dan Produktivitas Kerja. Bandung: CV. Mandar Maju.

Sukmadinata, N.S. (2006). Metoda Penelitian Pendidikan. Bandung: Remaja Rosdakarya.

Soegiyono. (2001). Metoda Penelitian Administrasi. Bandung: Alfabeta.

Soegiyono. (2009). Metoda Penelitian Kuantitatif, Kualitatif, dan R\&D. Bandung: Alfabeta.

Soegiyono. (2010). Statistika untuk Penelitian. Bandung: Alfabeta.

Yulifah, Rita, Yuswanto Tri. (2009). Komunikasi dan konseling dalam kebidanan. Jakarta: Salemba Medika. P. 42, 48-50. 